\title{
Emergency Lawmaking after 9/11 and 7/7
}

\author{
Adrian Vermeule $\dagger$
}

\section{INTRODUCTION}

Legislation passed in response to a serious terrorist attack is frequently criticized on two different grounds. First, the critic argues that the legislation grants "too much" power to the executive, relative to some substantive benchmark. Second, the critic impeaches the process by which the legislation was enacted, arguing that it was hasty, ill deliberated or ill informed, or panic-ridden. In practice, these substantive and procedural claims are often run together. Critics say that hasty or panicky emergency legislation systematically tends to grant the executive a blank check.

The claim of defective process relies on the circumstances of emergency lawmaking. On this view, the fog of uncertainty, emotions such as urgency and visceral fear, and the tendency of legislators and the public to "rally 'round the flag," all conspire to cause legislators to vote massive new powers to the executive, regardless of whether those powers are rationally justifiable. By contrast, my thesis will be that the circumstances of emergency lawmaking do not create a systematic tilt towards increasing executive power beyond the point that a rational legislature ${ }^{1}$ would specify. The very forces that empower the executive in emergency lawmaking also hamper the executive's ability to obtain the legislation it desires. The emotions unleashed by an emergency, the perceived need to react urgently, the widespread sense of political solidarity transcending partisanship, and the radical uncertainty of the situation - all these can be and are exploited by civil libertarians, the

$\dagger$ Professor of Law, Harvard Law School. I wish to acknowledge a general debt of inspiration to Mark Tushnet's studies of political controls on eunergency powers, although my views differ from Tushnet's. See generally, for example, Mark Tushnet, The Political Constitution of Emergency Powers: Some Lessons from Haindan, 91 Minn L Rev 1451 (2007); Mark Tushnet, The Political Constitution of Emergency Powers: Parliamentary and Separation-of-Powers Regulation, 3 Intl J L in Context 275 (2008). For helpful coinments, thanks to Jack Goldsmith, Eric Posner, Philip Rumney, Matthew Stephenson, Cass Sunstein, Mark Tushnet, workshop participants at Harvard Law School, and participants at a conference held at Harvard Law School to discuss Cass R. Sunstem, Worst-case Scenarios (Harvard 2007). Thanks to Elisabeth Theodore and Jennifer Shkabatur for helpful research assistance.

1 By a "rational legislature," I mean one that updates its risk assessments as the evidence warrants (given whatever evidence it is cost-justified to acquire) and that delegates new power to the executive accordingly. 
political opposition, and other camps in order to constrain the transfer of new powers to the executive.

The point is not that executives do not receive increased authority during emergencies; they usually do. The question, though, is whether they receive more new authority than rational legislators would provide. Assume that, after a terrorist attack, the ideal or optimal level of new delegation to the executive is greater than zero. ${ }^{2}$ The ideal level can be set by the preferences of voters, by some constitutional or moral theory, or anything else; all that matters is that some increase of executive power is desirable in emergencies-a view that has widespread support. Nevertheless, critics of emergency lawmaking clain that the circumstances of emergency lawmaking systematically tend to push the actual level of delegation beyond the ideal level. This I deny. The mechamisms and circumstances to which the critics point actually cut both ways, with unpredictable results in particular cases and no systematic effect overall, relative to the optimal aunount of new delegated authority. It is erroneous to emphasize only the factors that might bring about excessive delegation in emergencies, while ignoring those that might bring about insufficient delegation.

To focus the inquiry, I draw throughout on three recent episodes of emergency lawmaking: the enactment by Congress of the Authorization for Use of Military Force by Congress on September 14, 2001 (September 14 AUMF); ${ }^{4}$ the enactment by Congress of the Patriot Act on October 25,$2001 ;^{5}$ and the enactment by Parliament of the Terrorism Act 2006 on February 15, 2006. These three statutes, although of course a small set, offer substantial variation on several margins. The

2 See Philippe Aghion, Alberto Alesina, and Francesco Trebbi, Endogenous Political Institutions, 119 Q J Econ 565, 594 (2004) (providing a model in which crisis, including wars and other einergencies, increases the optimal degree of insulation of the government from public accountability and reduces the optimal number of checks and balances).

3 I define "einergency lawnaking" as the enactinent of antiterrorism statutes within one year of a major terrorist attack. Although this definition is partially arbitrary in that the public sense of einergency will persist for shorter or longer duration under varying conditions, a temporal restriction of some sort is warranted by the tendency of einergencies to dissipate over time as uncertainty diminishes and emotions decay. A more accurate definition is neither possible nor necessary for my purposes here.

4 Authorization for Use of Military Force, Pub L No 107-40, 115 Stat 224 (2001), codified at 50 USC $\$ 1541$ note (Supp 2002). The AUMF was not signed by the President until September 18,2001 . It is distinct from the AUMF enacted in October 2002 to authorize the second Iraq war. See Authorization for Use of Military Force against Iraq Resolution of 2002, Pub L No 107-243, 116 Stat 1498, codified at 50 USC $\$ 1541$ note (Supp 2002).

5 Uniting and Strengthening America by Providing Appropriate Tools Required to Intercept and Obstruct Terrorisin Act of 2001 ("Patriot Act"), Pub L No 107-56, 115 Stat 272.

6 Terrorisin Act 2006, ch 11 (UK). 
first two were enacted under a partially divided government in a separation of powers system; the third, under unified government in a parliamentary system. The first was enacted three days after the 9/11 attacks; the second, some six weeks after the attacks; the third was decisively shaped by a crucial government defeat in the House of Commons on November 10, 2005, some four months after the $7 / 7$ attacks in London, although it was not formally enacted until 2006. In the first two cases the statutes were enacted by overwhelming bipartisan majorities, although the final votes were preceded by frantic bargaining behind the scenes. In the third case the enacting majorities were relatively narrow (although, as we will see, cross-partisan at the decisive moments), and indeed the government lost on crucial votes.

In all of these cases, I claim, executives received substantially less in the way of new authority than they requested. Although those requests were, in part, initial bargaining positions that the executive expected to be cut down to size, tracing the processes of these enactments shows that in each case the executive partially lost control of the situation, hampered by the very circumstances that most concern civil libertarian critics. In the end, in each case, the executive had to make substantial compromises to obtain new powers. The resulting delegations were generated by a complex mix both of rational legislative deference, given an updated assessment of the threat, and of nonrational or boundedly rational processes. My main suggestion is that the latter processes can hamper as well as enable the expansion of executive powers; relative to the ideal level of emergency delegation, however defined, the results are unpredictable in any given case. Although some increase in executive power usually occurs after an attack, the increase may be less than optimal; the circumstances of emergency lawmaking may cause insufficient delegation as well as the excessive delegation that civil libertarians fear.

The discussion is organized thematically, rather than statute-bystatute. Part I introduces the three lawmaking episodes I shall draw upon throughout. Part II discusses some of the emotions that intensify during emergencies, particularly urgency and fear. Part III discusses partisanship during emergency lawmaking and contrasts partisanship

7 At the time, the House was controlled by Republicans and the Senate was controlled (though barely) by Democrats. For the general significance of divided government in a separation of powers system, see Daryl J. Levinson and Richard H. Pildes, Separation of Parties, Not Powers, 119 Harv L $\operatorname{Rev} 2311,2315$ (2006) ("The practical distinction between party-divided and party-unified government rivals in significance, and often dommates, the constitutional distinction between the branches in predicting and explaining interbranch political dynamics."). 
with group solidarity. Part IV discusses the emergency conditions of uncertainty and ignorance, and the cognitive strategies legislators use to make uncertainty manageable. A brief conclusion contrasts rational reasons for delegating emergency powers to the executive with nonrational causes of such delegation.

Throughout, I focus on emergency lawmaking following masscasualty terrorist attacks, while ignoring emergency lawmaking in other types of security emergencies, economic emergencies, or emergencies following natural disasters. ${ }^{8}$ Moreover, I restrict the discussion to the standard procedural critique of emergency lawmaking after a terror attack. Although I believe that the emergency delegations of power to the executive that resulted from these episodes were not obviously broader than would have been enacted by a strictly rational legislature updating its assessment of terrorist threats, that substantive claim is not part of my thesis here.'

\section{THREE EMERGENCY STATUTES}

I begin with just the essentials, reserving most of the theoretically significant details for the later discussion.

\section{A. September 14 AUMF}

Passed by Congress three days after $9 / 11$ and in the white heat of the emergency, one might expect to find in the September 14 AUMF, if anywhere, an exercise in haste and blank-check delegation to the executive. Surprisingly, however, the AUMF resulted from a process of tough bargaining among the White House, Democratic leaders in the Senate, and Republican leaders in the House. ${ }^{10}$

The White House's initial proposal provided that

8 For a somewhat similar claim about legislation after environmental disasters, see Matthew E. Kahn, Environmental Disasters as Risk Regulation Catalysts?: The Role of Bhopal, Chernobyl, Exxon Valdez, Love Canal, and Three Mile Island in Shaping U.S. Environmental Law, $35 \mathrm{~J}$ Risk \& Uncertainty 17, 19 (2007). Kahn's counterintuitive finding is that individual legislators were less likely to vote in favor of bills proposed after, and tied to, highly salient environmental disasters, in part because the bills under consideration were apparently extreme.

9 The substantive claim is defended in Eric A. Posner and Adrian Vermeule, Terror in the Balance: Security, Liberty, and the Courts 4-5 (Oxford 2007).

10 The best treatments of the circumstances surrounding the passage of the AUMF are Curtis A. Bradley and Jack L. Goldsmith, Congressional Authorization and the War on Terrorism, 118 Harv L Rev 2047 (2005), and David Abranowitz, The President, the Congress, and Use of Force: Legal and Political Considerations in Authorizing Use of Force against International Terrorism, 43 Harv Intl L J 71 (2002). 
the President is authorized to use all necessary and appropriate force against those nations, organizations, or persons he determines planned, authorized, harbored, committed, or aided in the planning or commission of the attacks against the United States that occurred on September 11,2001, and to deter and pre-empt any future acts of terrorism or aggression against the United States."

Other authorities proposed by the White House included a request that Congress give the President standing authority to appropriate whatever sums he deemed necessary to fight terrorism, that Congress waive any restrictions on foreign assistance, and that relevant congressional committees acquiesce in restrictions on the provision of classified or "sensitive" information. ${ }^{12}$

These proposals, however, were quickly and decisively rejected by legislative leaders, apparently on a bipartisan basis. ${ }^{13}$ The decisive worry mvolved not principally civil liberties, but the institutional power of Congress vis-à-vis the executive branch: "Given the breadth of activities potentially encompassed by the term 'aggression,' the President might never again have had to seek congressional authorization for the use of force to combat terrorism." Accordingly, "[a] consensus quickly developed that the authority should be himited to those responsible for the September 11 attacks, and to any country harboring those responsible." ${ }^{\prime 5}$ The final clause in the White House proposal, underlined above, was transformed into a purpose clause that limited the President's authority by requiring a nexus to the perpetrators of $9 / 11$ and that deleted sweeping powers to fight "terrorism" and "aggression.,"16

11 Draft Joint Resolution to Authorize the Use of United States Armed Forces against Those Responsible for the Recent Attacks Lunched [sic] against the United States, submitted to the Senate on Sept 12, 2001, quoted in 147 Cong Rec S 9949 (Oct 1, 2001) (emphasis added).

12 See Karl K. Schonberg, Global Security and Legal Restraint: Reconsidering War Powers after September 11,119 Polit Sci Q 115,117 (2004).

13 The rejection is clear; the bipartisan basis is implied by Abramowitz. See Abramowitz, 43 Harv Intl L J at 73-74 (cited in note 10) (observing that Congress, one house of which was controlled by Republicans, came to a consensus to restrict the President's plan to only those responsible for 9/11).

14 Id at 73.

15 Id at 74 .

16 In the final version, the operative section of the AUMF states:

[T] he President is authorized to use all necessary and appropriate force against those nations, organizations, or persons he determines planned, authorized, committed, or aided the terrorist attacks that occurred on September 11, 2001, or harbored such organizations or persons, in order to prevent any future acts of international terrorism against the Umited States by such nations, organizations or persons. 
Besides insisting on this relatively narrow authorization, legislators charted a middle course on many dimensions. Procedurally, they rejected amendments that would have imposed explicit periodic reporting requirements, but similar requirements were imposed by implication, through a cross-reference bringing the AUMF under the War Powers Resolution. ${ }^{17}$ Substantively, legislators declined to make it textually explicit that the authorization was only for the use of military force abroad, although many legislators so claimed during the debates. ${ }^{18}$ By the same token, however, legislators successfully resisted last-minute pressure from the White House-despite the extreme urgency of the situation - to insert the words "in the United States" so as to give the President express authority to use military force against terrorism domestically. ${ }^{19}$ Commentators have noted that "the requests from the White House in response to this crisis were particularly breathtaking, and the results of many of these proposals were far narrower than those put forth initially by the President. ${ }^{, 20}$

\section{B. The Patriot Act}

This 342-page statute defies easy summary, and in any event some excellent overviews are available. ${ }^{21}$ I merely say that the statute contains a variety of measures expanding law enforcement powers to conduct searches and surveillance; enacts prophylactic measures against illegal money laundering and financial transactions by terrorist groups; creates some new substantive crimes; and adjusts some rules of immigration and federal criminal procedure. As enacted, the meas-

17 See Abramowitz, 43 Harv Intl $\mathrm{L} \mathrm{J}$ at 76 (cited in note 10) (describing how provisions referencing the War Powers Resolution were adopted but more specific limitations were not).

18 See id at 75 (describing how, although inserting "abroad" was suggested, it was not inserted).

19 See Tom Daschle, Power We Didn't Grant, Wash Post A21 (Dec 23, 2005) (reporting that Senate leaders rejected the addition suggested by the White House minutes before voting on the bill).

20 Abramowitz, 43 Harv Intl L J at 74 n 8 (cited in note 10) (emphasis added).

21 See generally, for example, Beryl A. Howell, Seven Weeks: The Making of the USA PATRIOT Act, 72 Geo Wash L Rev 1145 (2004) (detailing the chronology of the Patriot Act's passage and some of the political compromises that shaped its final form); Bernard D. Reams, Jr. and Christopher T. Anglim, 1 USA PATRIOT Act: A Legislative History of the Uniting and Strengthening of America by Providing Appropriate Tools Required to Intercept and Obstruct Terrorism Act, Public Law No. 107-56 (Hein 2002) (presenting, in a five-volume set, the Patriot Act and the legislative history and debate that led to its passage). 
ure contained a sunset provision for many of the more controversial provisions. $^{22}$

The final version differed in major respects from the Administration's first draft, which was called the Anti-Terrorism Act (ATA). That draft contained several provisions that provoked opposition from civil libertarian legislators in both parties, such as a grant of power to the attorney general to detain any alien indefimitely on national security grounds, without judicial review. The opposition was sufficiently intense that the House Judiciary Committee, with a Republican majority, rebelled and refused to mark up the bill. ${ }^{23}$ The ATA as such died; the final enactment combined a draft bill by Senator Leahy (the USA Act), a consensus bill developed by House Republicans and Democrats (the Patriot Act), and Administration provisions.

Overall, "[t]he administration did not get everything it asked for in the draft Anti-Terrorism Act. The Administration also got a lot it did not ask for. ${ }^{24}$ The final enactment, for exaniple, sharply cut back on the Administration's request for the power to detain aliens indefinitely without review; the statute only allowed detention for seven days and added an express right of judicial review. ${ }^{25}$ Moreover, the statute contained several civil libertarian provisions inserted by House Republicans, including a federal cause of action for executive release of wiretap information, a provision establishing an inspector general for civil liberties and civil rights in the Department of Justice, and the sunset provisions, which House Republicans insisted upon retaining despite vehement objections front the President's negotiators. I shall return to this last episode below.

\section{Terrorism Act 2006}

The Terrorism Act 2006 was introduced on October 12, 2005, enacted on February 15, 2006, and came into force at the end of March.

22 The provisions were due to lapse on December 31, 2005. After several extensions by Congress to allow time for political bargaining, the provisions were slightly modified to accommodate some civil libertarian concerns (although by no means all); most were made permanent, although two were reenacted with a new sunset that will expire in 2009. See Brian T. Yeh and Charles Doyle, USA PATRIOT Improvement and Reauthorization Act of 2005: A Legal Analysis (Congressional Research Service, Dec 21, 2006), online at http://www.fas.org/sgp/crs/intel RL33332.pdf (visited June 8, 2008).

23 See Howell, 72 Geo Wash L Rev at 1161-62 (cited in note 21) (explaining that despite Administration efforts to pass the bill as quickly as possible, bipartisan objections from both the House and Senate Judiciary Committees forced a delay of the markup).

24 Id at 1178-79.

25 1d at 1204 . See also Patriot Act $\$ 412$. 
Between the introduction and the enactment a political drama unfolded. The draft bill emerged from multiparty consultations aimed at achieving consensus, and the Conservatives and Liberal Democrats, rather than the Labour government, originated some two-thirds of the provisions in the final bill. ${ }^{26}$ The provisions enjoying widespread support included a range of new criminal offenses, such as preparation or training for terrorist acts and the making or possession of materials usable in such acts. The Act also gave the Home Secretary wider powers to proscribe terrorist groups.

Consensus, however, broke down over two provisions. In the first case, the initial draft included a broad offense of "glorifying, exalting or celebrating terrorism." ${ }^{27}$ Facing vehement criticism from the other parties and civil liberties groups, the government was forced to water down this provision by including a requirement that the glorification be intentional or reckless. ${ }^{28}$ More serious yet was the controversy over detention of suspected terrorists, which reached such proportions that it eventually threatened to bring down the government of Prime Minister Tony Blair. On November 9, the government introduced an amendment, already the subject of massive public attention, which proposed to extend the maximum detention period from fourteen days to ninety days. Conservatives and Liberals opposed the measure, but Prime Minister Blair refused all offers of compromise. Rebels within the Labour party broke ranks, and the amendment was defeated; the rebels then proposed an amendment to extend the detention period to twenty-eight days, which was carried. ${ }^{29}$ Following this defeat, Prime Minister Blair was forced to fend off claims that the government's defeat occurred on a de facto "issue of confidence," which under British parliamentary conventions would have forced the government to step

26 See Terrorism Bill, 439 Parl Deb, HC (6th ser) 351 (2005) (David Davis) (contending that the opposition parties supported the government).

27 See Nigel Morris, Leak Shows Clarke's Unease over Plan to Detain Suspects, The Independent (Sept 16, 2005), online at http://www.independent.co.uk/news/uk/crime/leak-showsclarkes-unease-over-plan-to-detain-suspects-507032.html (visited June 8, 2008).

28 See James Ball, After the Bombs: The Key Political Events that Followed the London Bombings, Guardian Unlimited (July 4, 2006), onlime at http://www.guardian.co.uk/ attackonlondon/story $/ 0,1812299,00$.html (visited June 8,2008 ). For the final mens rea requirement, see Terrorism Act 2006, ch 11, pt I, \& 1(2)(b) (UK).

29 George Jones, Blair's Blackest Day: MPs Reject 90-Day Terror Detention: PM Suffers First Commons Defeat, Daily Telegraph 1 (Nov 10,2005) (recounting that forty-nine Labour MPs voted against Blair on the ninety-day detention period, helping inflict the first defeat of his eightyear premiership). 
down and call new elections. On February 15, 2006, the chastened bill passed by a slim and largely partisan majority.

\section{Four Baselines}

In all of these episodes, the analyst may compare the final enactment to one of four different baselines. The first is the legal status quo ante; the second is an optimal or ideal (from the analyst's point of view) set of legal rules; the third is the counterfactual legal baseline that would have obtained had the executive's initial proposals been enacted; the fourth is the counterfactual legal baseline that would have obtained had the executive's true preferences been enacted. For the security-minded, the second baseline often corresponds to the third, while for civil libertarians the second often corresponds to the first. There is, however, no guarantee of this in either case; the securityminded may think even the executive's proposals too faint-hearted, while the civil libertarian may think the legal status quo ante was itself insufficiently protective.

In presenting the thumbnail sketches above, my implicit concern has been to show that the choice of baselines is highly consequential. Civil libertarians usually compare the enacted statute to the first or second baseline, in order to argue that the final legislation granted a great deal of new power to the executive and to set up a further argument that the emergency circumstances that produced the new legislation undermined legal checks on executive powers. In all three episodes, however, those circumstances also constrained the resulting delegations. Although executives obtained increased powers, emergency circumstances did not systematically push in the direction of ever-greater delegation, or so I suggest. There is no systematic reason to think that the new delegations exceeded the level that a rational legislature would specify.

Comparing the final enactment to the third and fourth baselines is also illuminating. In emergency lawmaking after $9 / 11$ and $7 / 7$, executives obtained far less than they proposed. ${ }^{31}$ They also obtained less

30 More recently, Prime Minister Blair's successor, Gordon Brown, has proposed extending the twenty-eight-day maximum to forty-two days. It is unclear whether the proposal will succeed. See Terror Detention Plans Unveiled, BBC News (Jan 24, 2008), online at http://news.bbc.co.uk 12/hi/uk_news/politics/7205939.stm (visited June 8, 2008).

31 Although I do not develop the comparison here, it is striking that in the 2006 Military Commissions Act, a nonemergency statute, the Bush Administration ended up obtaining almost everything that it proposed, while in the emergency episodes it did not. This might support the hypothesis that the Administration did better overall when the forces that constrain the executive in emergency lawmaking had ceased to operate. Nevertheless, there are two alternative hypothes- 
than their true preferences. The third baseline (the executive's initial proposals) will differ from the fourth (the executive's true preferences) if executives make strategic proposals or stake out extreme bargaining positions. In general, what executives and other political actors ask for is at best weak evidence of what they want. Nevertheless, officials are more likely to drop the mask in emergencies than in normal times, revealing true preferences under the pressures of emotion and the disruption of policymaking routines. Thus I adduce indirect evidence that in these cases executives (1) incautiously revealed their true preferences; and (2) in significant ways lost control of the legislative process, meaning that they obtained not only less than they asked for, but less than they desired.

\section{EMOTIONS}

\section{A. Urgency}

During emergency lawmaking, the sense of urgency is widespread. Typically, almost everyone agrees that (1) something must be done; and (2) something must be done soon. Although these two propositions are hardly identical, it is characteristic of emergency lawmaking that they are frequently conflated. A rational actor faced with a possible threat will collect less information and deliberate less as the opportunity costs of inaction increase, but it is blindingly obvious that after $9 / 11$ many legislators simply felt prolonged inaction to be intolerable, even if it meant striking out blindly. As one Representative put it in the debates over the September 14 AUMF:

We do not know for sure who the enemy is, where he may be found, or who may be harboring him. Congress is giving the President the authority to act before we have answers to these basic questions because we cannot be paralyzed. We need to answer this treacherous attack upon our people on our soil, and that is why we grant the President this broad grant of authority.

es as well: (1) In the former episode, the Administration might have simply asked for less because nonemergency circumstances are a less favorable environment in which to press for the maximum. (2) By 2006, the Administration's credibility was in tatters, so the comparison does not shed light on the effects of emergency and nonemergency conditions holding the executive's credibility constant. Even if (2) is correct, the Administration's lack of credibility was itself at least partly a product of its tendency to overclaim and overpress in the episodes I shall discuss below, although the Iraq War was no doubt the largest factor.

32147 Cong Rec H 5649 (Sept 14, 2001) (Rep Spratt) (eınphasis added). 
Critics say that the sense of urgency puts pressure on legislators to accede to executive proposals. This is true, but the critics overlook that urgency also puts pressure on the executive to accede to legislative proposals. Urgency is a knife that can cut either way. What matters in emergency lawmaking is not the parties' urgency relative to the baseline of normal times, but their urgency relative to each other. Even if legislators experience far more urgency than during normal times, if the executive is subject to yet greater urgency, legislators' preferences will tend to prevail in the bargaining that is part and parcel of emergency lawmaking.

Here we need to distinguish between two possible senses of urgency, which correspond to two different sources of bargaining disadvantage: impatience to enjoy the fruits of agreement and fear of the consequences of nonagreement. ${ }^{33}$ In particular cases of emergency lawmaking, either or both can increase legislators' bargaining power while decreasing that of the executive. As to the first factor, in the standard Rubinstein bargaining model, the more impatient party - the party who discounts the future more heavily-loses more from delay in reaching agreement and will tend to offer greater concessions. ${ }^{34}$ Where the executive is more impatient than the dominant legislative coalition, the executive will accede. The sense of urgency created by the emergency loads the dice in favor of a relatively more patient legislature, even if the legislature is much less patient than in normal times.

In the bargaining over the Patriot Act, a crucial moment occurred when President Bush's negotiators objected strenuously to the final version because it contained a sunset provision they found objectionable.

[Senator Tom] Daschle, who knew how badly Bush wanted to avoid any delay in signing the legislation, turned to the [White House negotiator] and smiled. "Mr. Flanigan, does this mean the

33 Here I am eliding a possible distinction between "urgency" and "impatience," proposed by Jon Elster, in which the former refers to preference for immediate action over delayed action, and the latter to a preference for immediate reward over delayed reward. See Jon Elster, $E x$ plaining Social Behavior I54-55 (Cambridge 2007). I use "urgency" to cover both phenomena, which as far as I can tell were largely coextensive in the cases I draw upon here.

34 See Abhinay Muthoo, Bargaining Theory with Applications 51-55 (Cambridge 1999) (arguing that because the less patient player places greater value on present action, the less patient player has greater costs of haggling-each successive counteroffer further lengthens the time before that benefit is received - which lead to decreased bargaining power). 
president will veto the bill?" he asked. "And then of course," Flanigan acknowledges now, "I had to say no.",

Here the President's greater relative impatience caused him to incur a bargaining loss.

As to the second factor, where one party stands to lose relatively more if no agreement is reached at all, the other party will reap the greater share of the gains from agreement. During emergencies, both executive and legislators will incur large political costs from failure to agree on new action. In particular political circumstances, however, the executive might lose relatively more from gridlock than will legislators. Legislators are under enormous pressure to take a strong stand on national security. By the same token, presidents and prime ministers are under enormous pressure to assert decisive leadership during emergencies. Although the critics emphasize that this factor gives the executive powerful incentives to rush through emergency legislation, they overlook that it simultaneously ensures that legislators who stand to lose less from a breakdown of negotiations will have the whip hand in bargaining. Civil libertarians often argue that presidents (at least first-term presidents) worry about reelection and thus have short time horizons. ${ }^{36}$ But if presidents focus on the short run more than legislators, or at least senators, it means that the circumstances of emergency lawnaking will tend to give legislators disproportionate bargaining power.

Moreover, the political costs of failure to reach agreement are spread over all legislators, whereas a president or prime minister will bear a larger individual share of the costs of failure. If there is another attack, the president will receive most of the blanie, and even if Congress is blamed, each individual legislator bears only a sinall fraction of the resulting costs. The ability of each legislator to externalize political costs onto other legislators strengthens the ability of each to resist pressure froin the executive or party leaders. Even if the latter wants to push the rank and file to give the executive branch whatever emergency powers it wants, individual legislators can shirk, free-ride, or quietly resist without much fear of being singled out for blaine by an

35 Robert O'Harrow Jr., Six Weeks in Autumn: A Year Ago, as a Nation Reeled from Attack, a Battle Was Joined for America's Future. Not in Afghanistan. In Washington, Wash Post W6 (Oct 27, 2002) (emphasis added).

36 For a particularly clear statement of this view, see Ilya Somin, Systematic Shortcomings of Broad Executive Power in Times of Crisis, Volokh Conspiracy (Aug 23, 2007), online at http:/www.volokh.com/posts/1187914017.shtml (visited June 8, 2008) (comparing presidential tenure of four or eight years with Supreme Court tenure of twenty-six years on average and potentially very lengthy congressional tenure). 
aroused public. These dynamics of collective action make emergency bargaining with legislatures more difficult for the executive than it would otherwise be.

Finally, it is worth underscoring that many critics make a mistake when they point to the rapidity with which an agreement is reached in emergency lawmaking, and then infer that the executive rammed through its proposals. In the standard bargaining model, rational bargainers will reach agreement in the first round; differential impatience or differential costs of nonagreement will affect only the terms on which the bargain is struck. In real-world bargaining, of course, holdouts, posturing, and strategic delay are common, but the absence of these things hardly means that one particular party prevailed on all terms. In the example of President Bush's objections to the Patriot Act, once the congressional negotiators called the President's bluff, both sides anticipated the final result and reached agreement right away, on terms favorable to legislators.

\section{B. Fear}

Closely related to urgency is fear. Here a useful distinction is between prudential and visceral fear: the former is a state of heightened caution that is perfectly compatible with rational updating of threat assessment while the latter is a genuinely hot emotional state that in some sense bypasses rationality. (I shortly attempt to describe this sense more specifically.) Critics of emergency lawmaking rarely draw the distinction in explicit terms but may charitably be understood to argue implicitly (1) that visceral fear is a dominant emotion in emergency lawmaking; and (2) that visceral fear causes legislators to grant massive power to the executive, perceived as a strong protector. I shall question assumption (2). Even if the claim is correct so far as it goes (as I shall assume for discussion's sake), it is seriously incomplete. Visceral fear does not automatically and necessarily translate into any particular political response. Rather, like other emotions, visceral fear is politically indeterminate in two senses. First, a range of actions, with opposing political tendencies, may result from visceral fear; there is no unique mapping from emotion to action. Second, visceral fear may have simultaneous and countervailing political effects, both causing legislators to grant power to the executive and making them fearful of doing so. I do not, of course, claim that these opposed tendencies exactly cancel each other out; we know too little to assess their relative 
magnitudes, which are doubtless highly dependent upon circumstances. Nevertheless, critics of emergency lawmaking systematically overlook one set of effects.

To explain these claims, I begin by drawing upon Terror Management Theory (TMT), which is to date the most developed account of the political effects of visceral fear. Terror management theorists begin from the premise that the fear of death is a major, usually subconscious, motivator of human belief, emotion, and action. Complexes of belief and emotion - "cultural worldviews"-are generated to cope with the suppressed mortality fear. When reminded of their own mortality by a highly salient event, people intensify their adherence to their cultural worldviews. Many react with leader worship, a desire to punish members of other groups, and approval of authoritarian tactics. Accordingly, in experiments after 9/11, terror management theorists initially found that reminders of mortality caused an increase in approval for President Bush among both liberals and conservatives. ${ }^{38}$ All this is broadly compatible with the account of visceral fear proffered by critics of emergency lawmaking.

There is, however, a major complication. Recall that the basic prediction of TMT is not that mortality salience causes political conservatism or authoritarianism but that it causes stricter adherence to one's antecedent worldview. What if that worldview is itself civil libertarian? It is then possible that the visceral fear of death produced by a highly salient terrorist attack will produce increased civil libertarianism among antecedently civil libertarian segments of the population.

Several TMT-inspired experiments have tested this and similar hypotheses, with ambiguous results to date. In an experiment conducted before $9 / 11$, liberal and conservative subjects were induced to think about their own mortality or (in a control group) a neutral topic, and they were then asked to evaluate two target persons, one hiberal and one conservative. The finding was that dislike of dissimilar others increased among conservatives but decreased among liberals, presumably because liberals clung more tightly to their antecedent value of tolerance. ${ }^{39}$ In a variation of the experiment, in which the value of to-

38 See, for example, Florette Cohen, et al, American Roulette: The Effect of Reminders of Death on Support for George W. Bush in the 2004 Presidential Election, 5 Analyses Soc Issues \& Pub Policy 177, 178 (2005) (finding that a majority of study participants "in a psychologically benign state" supported Senator John Kerry but a majority favored Bush after "a subtle reminder of death").

39 See Jeff Greenberg, et al, Terror Management and Tolerance: Does Mortality Salience Always Intensify Negative Reactions to Others Who Threaten One's Worldview?, $63 \mathrm{~J}$ Personality \& Soc Psych 212, 215 (1992). 
lerance was primed, mortality salience did not increase negative reactions to a target foreigner with anti-US opinions. ${ }^{\text {to }}$ In experiments after 9/11, the evidence has been mixed. Although, as mentioned above, mortality salience increased support for President Bush in the days before the 2004 election, a more recent experiment focused directly on a possible causal connection between mortality salience and support for extreme military action by American forces and for the $\mathrm{Pa}$ triot Act itself. The finding was that mortality salience did not increase support for the Act, or for military force, among antecedently liberal subjects, although it did for antecedently conservative subjects.

The ambiguity of TMT is an example of the larger indeterminacy of the action tendency of visceral fear. Fear in itself has no necessary political valence; panicky assessments of threats may cause overreaction to the threat of terrorist attacks but may also cause overreaction to the threat of executive abuses. The same mechanisms that are said to cause security panics, in which legislators demand repressive measures to curtail civil liberties (either because they are fearful in their own right or acting as slavish agents of fearful constituents), might in stead cause libertarian panics, in which legislators become all the more fearful of executive repression and abuse. ${ }^{2}$ Both types of panics may, of course, occur simultaneously, among different sectors of the population or among different political parties and different legislators.

There is ample evidence of both phenomena in post-9/11 lawmaking and, more broadly, in the post-9/11 period. As critics have supplied anecdotal evidence of security panics, I mention some anecdotal evidence of libertarian panic in the days after $9 / 11$. In the immediate aftermath of the attack, and in the period of debate and bargaining over the Patriot Act, civil libertarians became increasingly fearful of fundamental intrusions on civil liberties. On September 19, 2001, the Electronic Frontier Foundation warned that the Administration's draft antiterrorism bill would "dramatically alter the civil liberties landscape" and would "radically tip the United States system of checks and balances." ${ }^{\prime 3}$ Likewise, the director of the ACLU's Washing-

40 See id at 218 (finding that, although mortality salience increased disapproval of a dissimilar trait, it did not increase disapproval of a dissimilar other).

41 See Tom Pyszczynski, et al, Mortality Salience, Martyrdom, and Military Might: The Great Satan versus the Axis of Evil, 32 Personality \& Soc Psych Bull 525, 532-33 (2006).

42 I elaborate on this claim in Adrian Vermeule, Libertarian Panics, 36 Rutgers L J 871, 873-74 (2005).

43 Electronic Frontier Foundation, DOJ's Anti-terrorism Bill Would Dismantle Civil Liberties (Sept 19, 2001), onhine at http://www.eff.org/Censorship/Terrorism_militias/20010919_eff_ wiretap_pr.html (visited June 8, 2008). 
ton Legislative Office said that "people were worried. They just knew this was a recipe for government overreaching." At a meeting of civil libertarian interest groups from both the political left and right to coordinate strategies, turnout was the highest it had been in twentyfive years, and the group issued a reaffirmation of libertarian principles that was signed by more than 150 organizations and 300 law professors - only days after $9 / 11$. $^{45}$ Lobbying by these groups stiffened the spines of antecedently libertarian legislators bargaining with the White House over the Patriot Act. ${ }^{46}$ After the Patriot Act became law the libertarian panic went into higher gear, with many groups and jurisdictions condemning the Act on grounds that betrayed utter ignorance of its provisions.

Given the limitations of this sort of evidence, it is of course difficult to distinguish rational or prudential fear of bad governmental measures from panicky assessments, but the same is true in claimed security panics, where it is hard to untangle prudential from visceral fear; usually both play a role. Likewise, although civil libertarian interest groups doubtless had strategic incentives to exaggerate the threat to civil liberties in order to mobilize supporters, they were matched by the Bush Administration, which has been accused by many of strategically exaggerating terrorist threats, both in the enactment of the Patriot Act and more generally.

To repeat, the magnitudes of security panics and libertarian panics are unclear; I do not claim that libertarian panics and security panics somehow canceled each other out in the Patriot Act debates. Most plausibly, security panics peak near the beginning of an emergency, when the terrorist threat is most salient, ${ }^{48}$ while libertarian panics strengthen as the executive's response to the emergency unfolds over

44 O'Harrow, Six Weeks in Autumn, Wash Post at W6 (cited in note 35) (reporting that Laura Murphy, Director of the ACLU's Washington Legislative Office, made those remarks about the large turnout from various groups, including libertarian groups, immigration rights groups, and privacy groups, at the ACLU's Washington Office the Friday after 9/11 for a strategy session on protecting individual freedom and privacy).

45 See id (discussing the ten-point statement, entitled "In Defense of Freedom"). The tenpoint statement along with lists of signatories, including more than 150 organizations, 300 law professors, and 40 computer scientists, is available online at http://www.indefenseoffreedom.org (visited June 8,2008).

46 See Kam C. Wong, The Making of the USA PATRIOT Act I: The Legislative Process and Dynamics 29-32 (Berkeley Electronic Press Working Paper No 793, 2005) (explaining that the House Judiciary Committee held a "briefing" for civil liberties groups while the ATA was under consideration).

47 For evidence of libertarian panic after the Patriot Act's passage, see Vermeule, 36 Rutgers $\mathrm{L} J$ at $880-83$ (cited in note 42 ).

48 See Sunstein, Worst-case Scenarios at 54-60 (cited in note $\dagger$ ). 
time, perhaps because journalistic accounts of abuses become more salient. My main suggestion is just that the action tendencies of emotions are politically indeterminate, that multiple effects occur with no necessary valence for or against civil liberties, and that while some of those effects help the executive to secure expansive antiterrorism powers, other effects act as a political drag on its efforts to do so.

\section{PARTISANSHIP AND SOLIDARITY}

Here I comment briefly on the relationship between partisanship, the ordinary state of the political system in normal times, and the emotion of group solidarity, which dampens or overrides partisanship during emergencies. In the baseline preemergency political system, partisanship is generally the modus operandi. During emergencies, however, several mechanisms substantially attenuate partisanship, although only temporarily. I emphasize that this effect has ambiguous consequences. Although the urge to "rally "round the flag" is usually said to benefit the executive, who temporarily stands above the political fray, in other respects increased solidarity and decreased partisanship actually hamper executive attempts to obtain broad new grants of power from legislators.

\section{A. Bipartisanship and Executive Power}

A notable feature of the debates over all three acts is that civil liberties issues cut across party lines. Although the issue of antiterrorism legislation was often portrayed as roughly one-dimensional-how should the security-liberty tradeoff be struck? - legislators did not line up neatly by party along that single dimension. In the debate over the Terrorism Act 2006, when the Blair government suffered a major defeat on the issue of the maximum time limit for detention of terrorist suspects without trial, a decisive role was played by the Labour rebels-government backbenchers who provided the votes to defeat the government's measure and who proposed the alternative measure that carried. ${ }^{49}$ Likewise, in the debates over the Patriot Act, "[b]oth liberals and conservatives agreed that the proposals would grant the government excessive power and endanger civil liberties.... Ideologically opposed members such as Reps. Bob Barr (R-GA) and Maxine

49 See Fergal F. Davis, Extra-constitutionalism, the Human Rights Act and the "Labour Rebels": Applying Prof Tushnet's Theories in the UK, 4 Web J Current Legal Issues (2006), online at http://webjcli.ncl.ac.uk/2006/issue4/davis4.html (visited June 8, 2008) (contending that "rebellion" is necessary to control the executive, which necessarily has a majority in Parliament). 
Waters (D-CA) found themselves allied by a common concern about government overreach." ${ }^{\text {"so }}$ The Act's sunset provisions were introduced by Dick Armey, the Republican leader of the House, and were retained in the final bill despite strong opposition from the Republican

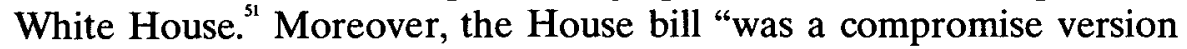
... designed to win broad support from both liberals and the right in a partisan Judiciary Committee." ${ }^{, 52}$ Altlough the final enactment was mostly modeled on the Senate version, it retained libertarian provisions on which the House had insisted, over the Administration's objections. ${ }^{53}$

As these episodes suggest, unusually low levels of partisanship liampered the executive when the consequence was to encourage or require more compromise with other parties than would usually occur. Critics of emergency lawmaking assume that the temporary weakening of partisanship and an increase in bipartisan unity benefits the executive, but this is a double-edged sword. In Parliament-and in Congress when the president's party controls one or both housespartisanship is the primary source of executive power over legislation.

Moreover, in the American episodes, the separation of powers introduced multidimensionality. Many legislators of both parties feared that the executive's new powers would enable it to encroach on legislative prerogatives and power. In the debates over the AUMF, congressional leaders from the two louses bargained as a unit with the White House and secured a provision stating that the AUMF was consistent with the War Powers Resolution; it can be plausibly claimed that they did so out of concern for congressional prerogatives. In both the AUMF debates and the Patriot Act debates, legislators of the President's party, such as James Sensenbrenner, forced concessions from White House negotiators in response to perceived institutional and personal slights. ${ }^{54}$ In the debates over the Terrorism Act, occurring in a parliamentary rather than separation of powers system, the theme of legislative prerogatives was necessarily muted.

50 Reams and Anglim, 1 USA PATRIOT Act at xl, xlvii (cited in note 21).

51 O'Harrow, Six Weeks in Autumn, Wash Post at W6 (cited in note 35).

52 Reams and Anglim, 1 USA PATRIOT Act at xlvi (cited in note 21).

53 Howell, 72 Geo Wash L Rev at 1172-73 (cited in note 21).

54 See Wong, Making of the USA PATRIOT Act at 31-32 (cited in note 46) (describing that Representative Sensenbrenner had a provision removed from the original ATA draft before allowing it to proceed because Attorney General John Ashcroft had not been cooperative enough). 


\section{B. The Cycle of Solidarity}

Stepping back from the political details, I try to offer a broader perspective on solidarity and partisanship by sketching a three-stage temporal sequence of emergency lawmaking, determined by the relative dominance of bipartisan solidarity, on the one hand, or partisan conflict, on the other. The first stage is one of genuine solidarity, the second one of ersatz solidarity, and the third one of open conflict. Although it is not inevitable, I believe this is a common sequence after a major emergency.

In the first stage, which typically arises in the immediate aftermath of a terrorist attack or other major emergency, some actors experience irresistible and quite genuine emotions of group solidarity, hatred of the other (somehow defined), and a desire to punish the other. Critics of emergency lawmaking typically argue that solidarity causes legislators to "rally "round the flag," and thus to vote massive power to the executive. This claim, however, is far too simple because the nature of these emotions is complex.

As we have seen, the evidence from TMT experiments on group solidarity is mixed. Political conservatives generally intensify their dislike of the other, but it is unclear whether liberals do so at all, or to the same extent. Furthermore, and crucially, the identity of the ingroup towards whom solidarity is felt is not predefined; it is to some extent manipulable by political entrepreneurs. In the debates over all three statutes, civil libertarian legislators attempted to exploit the ambiguity of solidarity by contrasting the evil terrorist other with enlightened civil libertarian America and Britain. These legislators typically argued that "if we forfeit our civil liberties, we hand the terrorists a victory." This sort of exploitation of solidarity to defend civil liberties puts some drag on executive attempts to acquire new powers, although the magnitude of the effect is unclear.

55 I thus disagree with Tushnet, 3 Intl $\mathrm{J}$ L in Context at $278 \mathrm{n} 18$ (cited in note $\dagger$ ) ("[W]e can expect that party discipline on issues of emergency powers will be reasonably strong at the outset of an emergency period but will decay as the emergency period stretches out."). To the contrary, at the beginning of the emergency, legislators float above partisanship on a cloud of solidarity; as the emotion decays, they maintain the pretense of doing so; later still, there is a return to partisan business as usual.

56 For examples of this class of argument, see O'Harrow, Six Weeks in Autumn, Wash Post at W6 (cited in note 35) (quoting Senator Patrick Leahy, "We do not want the terrorists to win by having basic protections taken away from us."); Peter Quayle, The Law of War Is a Hindrance, Not a Help, in Fighting Terrorism, Times (London) 4 (Sept 6, 2005) (quoting Lord Hoffmann, "The real threat to the life of the nation, in the sense of a people living in accordance with its traditional laws and political values, comes not from terrorism but from laws like these."). 
Whatever its scope, the stage of genuine solidarity is evanescent because the visceral emotions produced by terrorist attacks decay with extreme rapidity. Although I cannot prove this or even supply any rigorous evidence, it is apparent from journalistic accounts and from a comparison of the legislative debates over the September 14 AUMF, on the one hand, and the Patriot Act, on the other, that the emotional climate in Washington was changmg rapidly in the six or seven weeks between the two enactments. The former debates are full of unguarded expressions of emotions such as the thirst for vengeance and attachment to blood and soil. The latter debates are more standard legislative fare, mostly dry and technical. A similar pattern holds in the Britisll case as well. Buoyed by emotion, all parties initially pledged to develop consensus legislation, ${ }^{5}$ but political solidarity was short-lived.

In the second stage, then, genuine solidarity is replaced by ersatz solidarity. The emotions induced by the attack have decayed, but all actors preserve a façade of bipartisan unity while pressing more or less covertly for their preferred approach. Thus the negotiations over the Patriot Act proceeded "behind a veneer of national solidarity and bipartisanship., ${ }^{, 38}$ Altlougl this was to some extent genuine, in the sense that views of the optimal tradeoff between security and liberty cut across party lines, the underlying emotion of national unity was already fraying quickly, only a few weeks after $9 / 11 .^{39}$ In Britain, by the time of the culminating debate on the Terrorism Act 2006, some four montlis after the $7 / 7$ attacks, mutual public accusations of partisan advantage-seeking were rife; the third stage of open conflict had already been reached. ${ }^{60}$

I conjecture that after the first wave of emotional solidarity has dissipated, the façade of unity holds for a time because partisan actors fear the political costs of being (or being seen to be) the first to shatter it. What produces this cost is unclear. One possibility is that in postemergency periods, a public that is uncertain about the optimal

57 See Ball, After the Bombs, Guardian Unlimited (cited in note 28) (quoting government and opposition officials on July 7 and July 19, 2005); In Quotes: Government on Terror Plans, BBC News (Nov 8, 2005), online at http://news.bbc.co.uk/2/hi/uk_news/politics/4416846.stm (visited June 8, 2008) (quoting government officials on July 26, 2005).

58 O'Harrow, Six Weeks in Autumn, Wash Post at W6 (cited in note 35) (describing the closed-door battle over electronic eavesdropping).

59 See Howell, 72 Geo Wash L Rev at 1158 (cited in note 21) (describing statements of unity by both parties shortly before a "highly partisan offensive").

60 See 439 Parl Deb, HC at 375 (cited in note 26) (John Denham) ("The cross-party approach that was rightly struck in July is now self-evidently in tatters, with hon. Members being urged to vote for party advantage."). 
tradeoff between security and liberty uses a simple political heuristic: the first side to openly pursue partisan advantage thereby impeaches its own proposals. Whatever the source of the phenomenon, there is no doubt that it exists, and that it can seriously hamper executive attempts to obtain new powers. The executive's greater public visibility, especially in times of emergency, makes it more likely that his actions will be scrutinized for any sign of partisan motivation, whereas legislators can to some extent fly beneath the radar. In the British case, the Home Secretary was damagingly accused of "playing party politics with terror" when, after talks with opposing parties, he reneged on a promise to introduce compromise proposals. ${ }^{61}$ As this episode suggests, the executive's tendency to rise above party politics in times of emergency doubtless brings political benefits, but by the same token it imposes political constraints.

\section{UNCERTAINTY AND IGNORANCE}

A basic dilemma of emergency lawmaking is that (1) the status quo is unacceptable but (2) the costs and benefits of alternatives to the status quo are highly uncertain. Strikingly, almost every participant in all three lawmaking episodes agreed that policies would have to change and that the executive should receive some new powers, but they disagreed sharply about what type and extent of change would be desirable. Pervasive uncertainty accounts for at least part of their disagreements.

In the technical sense, uncertainty arises when decisionmakers can describe the set of possible outcomes but cannot attach probabilities to them; under ignorance, not even the outcomes are well defined. What is clear, at least to all but ideological Bayesians, ${ }^{62}$ is that emergency lawmaking cannot sensibly be described as lawmaking under conditions of risk, where decisionmakers both know the range of possible outcomes and can attach (epistemically reliable) probabilities to them. ${ }^{63}$ After $9 / 11$ or $7 / 7$, whether or not decisionmakers had a rough

61 Ben Russell and Nigel Morris, The Debate: The Terror Bill: MPs Berate Clarke for Refusing to Compromise on 90 Days, Independent 4 (Nov 10,2005) (describing Home Secretary Clarke's defense of his policies).

62 Bayesians believe that genuine uncertainty does not exist; subjective assignments of probability are always present, explicitly or implicitly.

63 Of course, some subjective probability can always be attached to any outcome or can be elicited by the experimenter; the question is whether those probabilities have any epistemic standing. For example, Cass Sunstein points out that subjective probabilities can be elicited from his dog. See Sunstein, Worst-case Scenarios at 160 (cited in note t). Moreover, subjective probabilities vary with the procedure used to elicit them. See Graham Loomes and Judith Melita, The Sensitivity of Subjective Probability to Time and Elicitation Method, 34 J Risk \& Uncertainty 201, 
sense of the spread of possible outcomes, they were clearly at sea in other respects. In the words of an insurance executive, "With terrorism, you can model what an impact might be on a specific building if there's a bomb of a certain size, but you can't model the probability of such an event happening."

Under uncertainty in the technical sense, a variety of decisionmaking approaches are possible, such as the maximin approach of acting so as to produce the best worst-case outcome. ${ }^{65}$ Nevertheless, even these approaches presuppose that the set of outcomes is well defined. I doubt that this condition is satisfied in the case of emergency policymaking after a terrorist attack, where officials are not only uncertain about whether they will win or lose the game but are even uncertain about exactly what game they are playing. Under this deeper ignorance, decisionmaking strategies become less formalized. ${ }^{66}$ I canvass some of these informal approaches and emphasize their double-edged character in the setting of legislative responses to the threat of terrorism. In such cases, uncertainty or ignorance do not necessarily or uniformly cause legislators to delegate increased power to the executive, although that is one possible reaction.

Boundedly rational agents can adopt any of several loosely defined approaches to action under severe uncertainty or ignorance. With the status quo placed out of reach, legislators in these episodes drew upon several approaches to simplify their decisionmaking tasks. I examine several approaches: the use of historical analogies; the use of political heuristics, such as the golden mean heuristic of supporting the intermediate proposal on a security-liberty dimension; and burden-shifting, or the idea that absent clear evidence one approach should have a natural priority. As we will see in each case, these simplifying strategies had ambiguous effects. They were invoked by the

203 (2007) (finding that type of event, elicitation method, and temporal scope of the event all change test subjects' subjective probabilities even for those subjects who have the ability to cope with objective probabilities well).

64 Daniel Gross, Capitalism vs. Terrorism: More and More American Companies Are Buying Terrorism Insurance. Uh-Oh., Slate (June 5, 2007), online at http://www.slate.com/id/2167685 (visited June 8,2008 ) (describing how predictions cannot be made without more actuarial data points).

65 See R. Duncan Luce and Howard Raiffa, Games and Decisions: Introduction and Critical Surveys 278-80 (Wiley 1957) (describing the maximin criterion for resolving decision problems under uncertainty, where there is a known utility payoff for each outcome, although the probability that a given outcome will materialize is unknown).

66 For a review of formal approaches to decisionmaking under both uncertainty and ignorance, see David Kelsey and John Quiggin, Theories of Choice under Ignorance and Uncertainty, 6 $\mathrm{J}$ Econ Surv 133 (1992). I believe that decisionmaking under ignorance is, by the very nature of the subject, best approached from the bottom up, through case studies of actual decisionmaking, rather than from the top down, through axiomatic approaches. 
executive to support broad grants of powers, yet also invoked by the political opposition and by civil libertarians to constrict new powers. The sharp increase in uncertainty that is characteristic of emergencies did not uniformly or inevitably work in favor of expansive executive power. Finally, I note that heightened uncertainty about public opinion during emergencies can hamper the executive as much as legislators.

\section{A. Historical Analogies}

Analogical reasoning is a familiar strategy for coping with informationally complex or highly uncertain environments. In the best case, analogies embed a great deal of tacit information, thereby economizing on the costs of explicit theorizing. But because analogies may be relevant on multiple dimensions, multiple analogies are possible. Which ones become dominant in the official mind and in public opinion may causally determine the direction and content of emergency lawmaking, at least in part. Although of course analogies may also be epiphenomenal-rhetorical points supporting positions reached on other, perhaps unexpressed grounds-they may still conveniently summarize legislative preferences that themselves have undoubted influence. Below, I examine some indirect evidence that the relevant analogies, or the complexes of preferences for which they are a shorthand, in fact had causal influence in shaping the final legislation.

Many competing historical analogies were invoked by participants in these debates. In the United Kingdom, Prime Minister Blair implicitly compared the $7 / 7$ attacks to $9 / 11$, despite the demonstrably smaller scale of the former episode. ${ }^{67}$ Likewise, security-minded legislators in the United States compared the 9/11 attacks to Pearl Harbor, ${ }^{68}$ despite the fundamental disanalogy that in the latter case the identity of the attacker, and its general military aims, were immediately clear. By contrast, when legislators approved the September 14 AUMF, there was uncertainty about who had even perpetrated the attacks; it was clear that bin Laden was involved, but not who else was, or what further capabilities the attackers might have. The uncertainty meant that legislators were constrained by circumstances to grant to the President at least a delegated power to attack any "organizations

67 See Blair: World Slept after 9/11, CNN (July 26, 2005), online at http://www.cnn.com/ 2005/WORLD/europe/07/26/london.politicians/index.html?iref=newssearch (visited June 8,2008).

68 See, for example, 147 Cong Rec E 1679 (Sept 20, 2001) (Rep Maloney) (quoting President Franklin Roosevelt's speech from the day after Pearl Harbor). 
and persons" involved (although, as we have seen, the President's broader request for power to fight "terrorism" was rejected).

On the other hand, civil libertarian legislators and groups invoked competing historical analogies, which were also of dubious relevance. In the American debates over the September 14 AUMF, many legislators expressed a concern that the authorization resembled the notorious Gulf of Tonkin Resolution-the congressional gesture of support for the war in Vietnam that the Johnson Administration had used to justify American involvement. Although the real worry in the Tonkin case was that the executive had purposefully exaggerated the attack that (it claimed) warranted a military response, and there was no credible evidence of purposeful exaggeration in the 9/11 case, the analogy seems indisputably to have had causal influence. Representative DeFazio spoke for many legislators when he stated in the House debates:

I had strong reservations about earlier drafts of the proposed resolution that authorized the use of force in an unprecedented, open-ended manner, far beyond that necessary to respond to the terrorist acts on our people, even far beyond that ceded to FDR in World War II. This is not a partisan issue for me. I would have opposed similar resolution language under a President of my own party.

This is an institutional concern for me. The earlier drafts ceded too much authority to the executive branch. In fact, one of the earlier drafts had provisions nearly identical to the Gulf of Tonkin Resolution, which had led to the unaccountable use of U.S. military forces in Vietnam. ${ }^{69}$

Although the House debates took place when the enactment of the Resolution was a foregone conclusion, there is no doubt that the knowledge that similar attitudes were held by many legislators influenced the ex ante bargaining and deliberation among the White House and legislative leaders.

In the British debates, it was suggested that the government was in effect reviving the sort of internment and detention policies that the United Kingdom had used, off and on, in Northern Ireland throughout the twentieth century. ${ }^{70}$ Moreover, an extremely awkward compar-

69147 Cong Rec H 5633 (Sept 14, 2001) (Rep DeFazio).

70 See, for example, Iain MacWhirter, We Must Save Our Greatest Contribution to Civilisation, Herald (Glasgow) 14 (Nov 9, 2005) (referring to lessons Conservatives learned from internment in Northern Ireland). 
ison for the government's ninety-day detention proposal was the fact that a similar ninety-day rule had been a centerpiece of the emergency policies of the apartheid regime in South Africa." The government rejected these analogies, and with good reason, since neither policy had incorporated genuinely independent judicial review, whereas the government's detention plan required repeated applications for judicial approval to extend the detention period to the maximum. But despite their inapposite character, there is no reason to doubt that these analogies moved at least some of the crucial Labour rebels whose civil libertarian commitments caused them to oppose the nimety-day detention maximum.

\section{B. Political Heuristics}

To cope with bounded information and rationality, it is common to adopt simple heuristics, or decisionmaking maxims. Such heuristics can misfire in systematic ways but can perform well in particular environments; more importantly, for boundedly rational actors they are superior to the hopeless attempt to consider all relevant information. At a higher level, however, a major problem is that multiple heuristics are possible, which means that the boundedly rational decisionmaker must attempt a kind of second-order decision ${ }^{72}$ about which heuristic to follow in cases of conflict. As we will see, the use of political heuristics by legislators created both opportunities and problems for executive officials attempting to secure emergency legislation.

In all three episodes of emergency lawmaking, the administration or government explicitly proposed the following simple heuristic: defer to experts. This simple heuristic, however, came under withering fire from legislators distrustful of the experts' competence or motivations or both. As to competence, the defer-to-experts heuristic is systematically in tension with another stock claim that executives often make during emergencies and that the executive in fact advanced in all three cases: the qualitatively new threats posed by mass-casualty terrorism require new policies and governmental authority. Under emergency conditions, the claim of changed circumstances that the executive uses to justify readjusting the balance of security and liberty itself tends to undercut the executive's claim to expertise because

71 See, for example, Tommy Sheridan, We'll Wake Up Soon in Blair's Police State, Mirror 29 (Nov 10, 2005).

72 See Cass R. Sunstein and Edna Ullmann-Margalit, Second-order Decisions, 110 Ethics 5, 7 (1999) (defming second-order decisions as "decisions about the appropriate strategy for reducing the problems associated with making a first-order decision"). 
there is no accumulated expert understanding of the new conditions. Executive officials must claim that although they themselves are at sea, legislators and the public are utterly adrift. While this is plausible, ${ }^{73}$ it is a more complex and less politically appealing position.

As for motivations, legislators and groups suspicious of executive aggrandizement or power-grabbing took advantage of the inherent circumstances of emergency lawmaking to make their charges plausible. In the Patriot Act debates, opposition forces pointed out that many of the Administration's proposals were the same ones that executive officials had tried unsuccessfully to obtain from Congress before 9/11. The resurrection of previously defeated proposals is in tension with the claim of changed circumstances and is consistent with bad motives, suggesting that executive officials are seizing on the new situation, with loosened political constraints, to push a preexisting agenda of executive aggrandizement. ${ }^{74}$ On the other hand, even the most well-motivated officials might adopt the same course, because of the urgency of emergency lawmaking. To create entirely new statutory schemes and antiterrorism strategies is a job for the long run; even if old proposals for expanding executive authority are somewhat inapposite to the case, an imperfect response now may be better than a more precise response later.

Despite their suspicions, legislators widely acknowledged that superior executive expertise rationally warranted some deference. The problem for legislators was how to balance that consideration against others. More generally, the decision problem facing legislators can be understood as optimizing the security-liberty tradeoff under conditions of near-total ignorance about the causal effect of various proposals on the two goods.

I conjecture that crucial legislators m many cases approached these problems by, roughly, deciding to give the Admimistration some but not all of what it requested. This is of course true of much non-emergency legislation as well, but I believe the tendency is exaggerated as uncertainty increases, as it does in emergencies. To explain this assertion, I now supplement the bargaining perspective developed above by considering the problem as one of decisionınaking by boundedly rational legislators acting under conditions of uncertainty or ignorance.

73 Or so it is argued in Posner and Vermeule, Terror in the Balance at 5 (cited in note 9).

74 See Mark Tushnet, Issues of Method in Analyzing the Policy Response to Emergencies, 56 Stan L Rev 1581, 1589 (2004) (claiıning that emergencies alter the constraints on political actors, allowing them to pursue their preexisting policy preferences). 
There are two general approaches. Starting from the baseline of the government's new proposal (not the legal status quo ante), legislators might cut back some part of the way toward the status quo, but not all the way. Alternatively, legislators might begin from the baseline of the status quo ante and adjust toward the executive's position. As we will see, the former procedure is more favorable to the executive, but the latter procedure was essentially followed during two of the three episodes under consideration.

More pointedly, we might see legislators as adopting something like a golden mean heuristic: support the intermediate proposal among those offered, defining intermediate along a security-liberty dimension. ${ }^{75}$ It is striking that at some suitably high level of abstraction, a heuristic of that sort captures the actual pattern of outcomes. In the British debates on the ninety-day limit, which had become the crucial point of disagreement among the contending forces, Parliament rejected the government's proposal in favor of the second-largest extension that was offered. In the Patriot Act debates, the Admimistration's initial proposal was quickly killed, and the bill produced in its place by compromise between House Republicans and Democrats became the centerpiece of the final enactment. In the debate over the September 14 AUMF, legislators rejected the Administration's initial draft but also voted down a proposal to require periodic reports from the President on the implementation of his new authority.

This golden mean heuristic, in various versions, is a common approach to decisionmaking under uncertainty or ignorance. Law students taking a required ethics exam in a multiple-choice format are advised, in lieu of studying, to pick the second most ethical answer. When choosing from a wine list, a customer aware of her own ignorance and seeking an optimal mix of price and quality might follow the maxim of picking a wine of intermediate price. ${ }^{76}$ If many environments require optimizing over two variables-such as price and quality, or liberty and security-and if in such environments the tradeoff rates across the variables typically produce a welfare curve with an internal maximum, then policy located at the extremes is likely to be suboptimal and the golden mean heuristic is sensible.

75 I assume here that the different senses of security and of liberty can be compressed into a single-dimensional measure. Not only is this a standard simplification, but in these cases it does no violence to the descriptions of the policy problem offered by the legislators and other actors who were involved.

76 Thanks to Dan Meltzer for supplying this example. 
As always, however, the golden mean heuristic can misfire, and can expose the decisionmaker to exploitation. First, in the literature on extremeness aversion, it has been shown that similar heuristics can produce preference reversals that violate the independence of irrelevant alternatives: a decisionmaker who chooses $A$ from the set $\{A, B\}$ might choose $B$ from the set $\{A, B, C\}$ if $B$ is portrayed as the intermediate option. ${ }^{n}$ A seller or other actor who structures the choice environment accordingly can exploit this tendency by including extreme options that are irrelevant, in the sense that they are never preferred to some other option, but that nonetheless affect the choice between the other options. A restaurant owner might increase the average price of the entrées that diners order by placing a very expensive entrée at the top of the menu. Similarly, in the literature on anchoring and adjustment, it has been shown that an agenda-setter can manipulate choices or estimates by making an initial suggestion that has an extreme value along relevant dimensions.

These results, however, are still not fully developed. A crucial question involves constraints on manipulation through anchoring or the introduction of irrelevant alternatives. One constraint is that the extreme claims necessary to manipulate boundedly rational actors in one setting might undermine the manipulator's credibility, in the same setting or before other audiences. In experiments on the anchoring effect of lawyers' demands for damages in personal injury cases, "[a]ward size and variability increased as the plaintiff's request increased but decreased with the most extreme request.", The first effect stems from anchoring, the second presumably from the loss of credibility that comes with making ridiculous demands. ${ }^{80}$ Would-be manipulators face similar tradeoffs when they benefit from maintaining their credibility over time and across different transactions, settings, or audiences.

77 See Amos Tversky and Itamar Simonson, Context-dependent Preferences, 39 Mgmt Sci 1179, 1183 (1993); Itamar Simonson and Amos Tversky, Choice in Context: Tradeoff Contrast and Extremeness Aversion, $29 \mathrm{~J}$ Marketing Rsrch 281,290 (1992).

78 See Mollie W. Marti and Roselle L. Wissler, Be Careful What You Ask for: The Effect of Anchors on Personal Injury Damages Awards, 6 J Experimental Psych: Applied 91,95-96 (2000).

79 Id at 91.

80 For example, when a plaintiff sued a dry cleaner for $\$ 54$ million for ruining a pair of pants, the case made the newspapers, and the plaintiff became a figure of fun. See Suevon Lee, Dry Cleaner Calls \$54 Million Lawsuit over Pants a "Nightmare," NY Times A25 (June 14, 2007). As further example of the ridicule this case generated in legal circles, a total of fourteen posts concerning this lawsuit were posted in the legal tabloid blog, Above the Law. See, for example, David Lat, Judge Roy Pearson: What a Prince, Above the Law (Aug 8, 2007), online at http:// www.abovethelaw.com/2007/06/judge_roy_pearson_what_a_prince.php (visited June 8, 2008). 
Another major constraint on anchoring is counter-anchoring: two can play the game." In the study of jury awards discussed above, "award size and variability decreased as the defense rebuttal decreased" (that is, as the defense's proposed damage award decreased). ${ }^{82}$ But credibility constrains counter-anchoring as well. When defense lawyers decreased their proposed awards from a relatively low figure to $\$ 0$, "the mean award increased and was higher than when the defense recommended [a low positive sum]., ${ }^{, 3}$

How did these effects and constraints operate in the post-9/11 period? In two of the three cases of post-9/11 emergency lawmaking, anchoring seems to have played little if any role. In the September 14 AUMF, part of the Administration's initial proposal, a clause asking for an open-ended grant of authority to fight terrorism both domestically and abroad, was instantly "[d]ismiss[ed] ... as an overreach and probably only an initial bargaining position", noncredible or implausible offer. The final version, however, retained some of the syntactic structure of the Administration's proposal and seems to have been generated through a process of adjustment from the baseline of the executive's initial version. Perhaps this represents a case where anchoring operated despite legislators' conscious dismissal of the proposal as extreme, although the simpler explanation is just that, apart from the objectionable clause, the rest of the proposal corresponded to legislators' preferences.

In any event, the evidence of anchoring effects is even weaker in the other two episodes. In the debates over the Patriot Act, " $[t]$ he Department of Justice contributed only about one-third of the provisions that became [the Act], and that one-third was significantly modified from what the Attorney General [initially] presented., ${ }^{, 85}$ In the case of the Terrorism Act 2006, the final twenty-eight-day maximum period for detention without charge was obtained not by downward adjustment from the government's ninety-day proposal, but by upward adjustment-a deliberate although quite arbitrary doubling-of the fourteen-day status quo. ${ }^{86}$ In the latter case, opponents of the ninetyday detention maximum employed counter-anchoring tactics, with

81 For the role of counter-anchoring in Supreme Court litigation, see Neal K. Katyal, Comment, Hamdan v. Rumsfeld: The Legal Academy Goes to Practice, $120 \mathrm{Harv}$ L Rev 65, 73-76 (2006).

82 Marti and Wissler, $6 \mathrm{~J}$ Experimental Psych: Applied at 91 (cited in note 78).

83 Id at 98 (explaining that rebutting witl a large figure or with $\$ 0$ did not significantly reduce awards compared to not rebutting but that introducing a low figure did).

84 Abramowitz, 43 Harv Intl L J at 74 (cited in note 10).

85 Howell, 72 Geo Wash L Rev at 1179 (cited in note 21).

86 See 439 Parl Deb, HC at 357 (cited in note 26) (David Winnick). 
appreciable effect. A number of MPs argued that the status quo period of fourteen days was the maximum period that would avoid challenge under the Human Rights Act $1998^{87}$ or was even itself excessive on libertarian grounds. ${ }^{88}$ David Davis, the Conservative Shadow Home Secretary, proposed a counter-anchor when he argued that "[i]n Australia ... there is fierce debate about an extension from two days to 14 days. Most of the other countries with similar judicial systems to ours have smaller, not greater, rights to detain without trial."

Although there is little evidence in these cases for successful anchoring or manipulation of legislators' extremeness aversion, there is clear evidence for the credibility cost of attempted manipulation. It has been claimed that the Bush Administration attempted to manipulate extremeness aversion by Supreme Court justices by staking out extreme legal positions in litigated cases. ${ }^{90}$ (If the median justice always splits the difference, then one always does best by claiming the whole pie.) Actually, the Administration's extreme litigating positions clearly damaged its reputation among the justices and among legal and political elites who found its claims implausible and disturbing." Likewise, the extreme claims made by the Administration about the Patriot Act damaged its credibility and made it harder to obtain further legislation: witness the abortive proposal for a "Patriot Act II.", This tradeoff between the potential benefits of manipulation and the

87 See Terrorism Bill, 438 Parl Deb, HC (6th ser) 932 (2005) (William Cash).

88 See 439 Parl Deb, HC at 347 (cited in note 26) (David Davis) ("After all, even 14 days is a damaging experience for someone who is innocent, so 90 days is an enormously damaging experience that could wreck lives, rum jobs and destroy relationships."); 438 Parl Deb, HC at 928 (cited in note 87) (Emily Thornberry) ("What concerns me deeply is the possibility that some scared, innocent Muslim teenager will be arrested on the say-so of someone else and a police officer's hunch, and locked up for 90 days.").

89439 Parl Deb, HC at 355 (cited in note 26) (David Davis).

90 See, for example, Katyal, Comment, 120 Harv L Rev at 73-76 (cited in note 81).

91 See Jack Goldsmith, The Terror Presidency: Law and Judgment inside the Bush Administration 157-62 (Norton 2007) (describing the aftermath of the leak to the press of the interrogation meinos in the wake of the Abu Ghraib scandal and the resulting loss of credihility for the Bush Administration).

92 The extent of the Administration's loss of credibility is seen in the following conspiracy theory about Attorney General Ashcroft's motives:

Before it was leaked to the Center for Public Integrity, a bill dubbed the Patriot Act II was in development at the Justice Department. The draft would have allowed for the stripping of American citizenship and the secret detention of citizens; and popular conjecture had it that Attorney General John Ashcroft was just waiting for another terror attack to roll the bill out. In that moment of national panic, a malleable Congress wouldn't resist.

Robyn E. Blumner, From Tommy Franks, a Doomsday Scenario, St Petersburg Times (Fla) 1 P (Dec 7, 2003). 
risk to credibility is an ever-present dilemma for executives in emergency lawmaking.

\section{Burden-shiftmg}

Under severe uncertainty, a comınon strategy is to simplify decisionmaking by allocating burdens of proof. The strategy of sticking with the status quo, discussed above, can be described as a special case of the burden-shifting approach. If there are positive costs of transition away from the status quo, then proponents of a move are given the burden of showing clear coinpensating (net) benefits. But if the status quo is ruled off the table, as is characteristic of emergency lawinaking, then there is no natural focal point for the burden-shifting approach to grasp. There will then be not only a first-order debate about the costs and benefits of alternatives, but a second-order debate about where the burden of proof should be placed as among the firstorder possibilities whose costs and benefits are unclear.

A particularly pure illustration of this dynamic arose in the final Commons debate about the relative merits of a fourteen-day, twentyeight-day, and ninety-day nıaximun timit for detention without charge. The main charge laid by niany opponents of the ninety-day proposal, and stressed by David Davis, the Shadow Home Secretary, was that the government had not niade out an "evidence-based case." That is, the government was unable to point to any actual case in which (1) the suspect was released due to the fourteen-day limit; (2) the ninetyday limit would have permitted the police enough tinie to collect sufficient evidence; and (3) a shorter time limit would not have been adequate. The reigning assumption ainong opponents was that, in alniost all cases, if sufficient evidence to charge could not be collected within fourteen days then it could not be collected at all. Although the Hoine Secretary, Charles Clarke, tried to rebut this clainı by pointing to a case in which a conspirator in the "ricin plot" of 2002 had fled the country after being released, the most Clarke could offer was a counterfactual speculation that the outcome "might have been very different." Even in that case, opponents could also claim that a twentyeight-day limit would have been sufficient as well.

93439 Parl Deb, HC at 349 (cited in note 26) (David Davis) ("The question before the House is this: have Ministers made a robust, convincing and evidence-based case for 90 days?").

94 Id at 337 (Home Secretary Charles Clarke) (quoting Deputy Assistant Commissioner Peter Clarke). 
As these dueling charges and responses show, the problem was the inherent uncertainty of counterfactuals. On the one hand, Davis was correct that the government could not demonstrate, rather than speculate, that the ninety-day limit was necessary. Precisely because the ninety-day limit was not the status quo, there was no body of past cases on which to base such a demonstration. As a Labour legislator pointed out, "We do not know, because it never happened." On the other hand, if there was no evidence-based case for the ninety-day limit, there was no evidence-based case for the alternatives either. Labour legislators supportive of the government thus tried to turn the tables on Davis by arguing out that the twenty-eight-day alternative rested on no better evidentiary basis. Davis then retreated to the high ground of uncertainty by claiming that although there was "some case for some extension [past the 14-day maximum] I have not yet seen any case for 21,28 or 90 days." ${ }^{, 96}$

Although this exchange revealed that Davis's charge against the government's proposal was arbitrarily selective, the fact that the government's proposal was the proposal at issue made Davis's charge rhetorically powerful. Although none of the competing proposals were evidence-based either, the Prime Minister was rightly seen to have overclaimed when he said that the need for the ninety-day maximum was "compelling.", A dilemma for the government in such cases is that while it benefits from making the first proposal, which enables the government to frame the debate, it is difficult to make an affirmative proposal based on counterfactual speculation. The fact that the government's proposal is inevitably the focus of discussion lends a superficial plausibility to the notion that the burden of proof lies on the government to demonstrate the need for the change. The profound uncertainty attending emergencies here hampers proposals to expand executive power through legislation.

\section{Focal Points}

It is implicit in the foregoing discussion that in the Commons debates over the Terrorism Act 2006, the grave uncertainties afflicting all sides and the nature of the problem meant that proponents of various views proposed competing focal points for new legislation. The status quo is of course a natural focal point - when in doubt, do nothing- 
but one that is placed out of reach by the circumstances of emergency lawmaking. Other focal points were explicitly debated. A Labour legislator attacked David Davis on the ground that "90 days was proposed because the police made the initial request. Why is the right hon. Gentleman rejecting the police's request for 90 days and trying to impose his own arbitrary deadline of 28 days?" - a gambit that ignored, as we have seen, that the government's proposal of ninety days could also be charged with arbitrariness. Thus a Conservative legislator rightly observed that "the time period [preferred by the government]-three months in all-seems to have been plucked out of the air."”

In general, all sides accused all other sides of picking arbitrary numbers, and all sides were right to do so. Indeed, this arbitrariness was so obvious that it was conceded by some, although not by the government (another instance of the overclaiming that seems to have contributed to the government's defeat). When David Winnick, the Labour rebel who first proposed the winning twenty-eight-day limit, was questioned about the basis for his proposal, ${ }^{100}$ he replied candidly that "given that we already have 14 days, and in view of the acute terrorist threat and the police request, I thought that it would not be unreasonable ... to double that to 28 days." ${ }^{101}$ A Labour loyalist then mocked Winnick's answer by asking: "Is my hon. Friend therefore telling the House that he feels that the terrorist threat in this day and age is only twice as bad as before? If he wants Members to support 28 days, he ought to give an evidence-based case." ${ }^{102}$ But evidence was irrelevant. Winnick's doubling was obviously an utterly arbitrary procedure, yet it yielded a focal point that the Labour rebels, who were unhappy with the government's proposal but had no better basis for any of the numerical alternatives, could use to coordinate their opposition.

\section{E. Uncertainty and Public Opinion}

During normal times, lawmaking on many subjects follows welldefined and relatively stable public opinion. Even if lawmakers are caught between opposing political camps, it is generally clear what those camps are and what they want. During emergencies, however, public opinion is still molten rather than solidified. Entrepreneurial actors can do more to shape it than during normal times. Moreover,

\footnotetext{
98 Id at 348 (Ian Lucas) (emphasis added).

99 Id at 338 (Kenneth Clarke).

100 See id at 357 (Jeremy Corbyn).

101 Id (David Winnick) (emphasis added).

102 Id at 358 (Shona McIsaac).
} 
apart from the intrinsic instability of public opinion during emergencies, there is also heightened uncertainty about what the public wants or will accept. The shape and intensity of the political constraints are less clear than during normal times, except for the iron constraint that the legal status quo must change. This added uncertainty acts as a randomizer that tends to equalize the chances of the political contestants: both the executive and opposition forces are more likely to make plausible-seeming mistakes about the political effects of their actions.

In the Patriot Act debates, the Administration clearly underestimated both the amount of resistance it would face from civil libertarian groups and diffuse public anxiety about "the phantoms of lost liberty." ${ }^{103}$ More crucially, the Admimistration does not seem to have realized, at least initially, that it would face an alliance between civil libertarians of the left and of the right. Because conservatives had been loyal supporters of the Administration on pre-9/11 matters of taxation and economic policy, it was not obvious, except in hindsight, that the same conservatives would be civil libertarians on matters of security policy. When the Republican-controlled House produced a more civil libertarian bill than the Democrat-controlled Senate, it was too late for the Administration to adjust; President Bush's implicit threat to veto the final product because it contained the sunset provision inserted by the House was rightly dismissed as noncredible.

Likewise, in the debates over the Terrorism Act 2006, Prime Minister Blair seems to have believed erroneously, but sincerely, that a large majority of the British public favored his ninety-day maximum limit for detention without charge. ${ }^{104}$ Although his statements before the government's defeat might be dismissed as strategic, intended to pressure wavering lawmakers, this does not explain why he reiterated his view after the vote, complaining that there was a "worrying gap" between the public's preferences and the votes of MPs. Shortly before the vote, a leading poll showed that 72 percent of the public supported the ninety-day maximum, with just 22 percent opposed. ${ }^{105}$ This poll, however, was methodologically controversial and may have elided the crucial distmction between (1) support for the government's desire to

103 Neil A. Lewis, A Nation Challenged: The Senate Hearing; Ashcroft Defends Antiterror Plan; Says Criticism May Aid U.S. Foes, NY Times A1 (Dec 7, 2001).

104 See Matthew Tempest, Blair Defiant as Pressure Mounts, Guardian Unlimited (Nov 10, 2005), online at http:/politics.guardian.co.uk/terrorism/story/0,15935,1639636,00.html (visited June 8, 2008).

105 See Sky News / YouGov Survey Results, YouGov (Nov 4-5, 2005), online at http://www. yougov.com/uk/archives/pdf/DBD050101009_1.pdf (visited June 8, 2008). 
change the status quo and (2) support for the government's particular proposal. $^{106}$

The latter possibility was illustrated by a BBC web-based poll, closed only on the very day of the vote, which showed that 41 percent supported ninety days, 7 percent supported forty-two days (an arbitrary tripling of the fourteen-day limit), 24 percent supported twentyeight days, and 28 percent desired to remain at the status quo of fourteen days. ${ }^{107}$ In the BBC poll, although the same 72 percent shown in the previous poll supported an increase from the status quo of fourteen days, a majority of 52 percent opposed an extension to any number greater than twenty-eight days. Web-based polls are flawed by selfselection; still, the BBC poll at least suggests that the Winnick proposal was a Condorcet winner - a proposal that could defeat any other in pairwise competition under a majority voting rule.

If we assume exogenous and fixed public opinion on the detention issue, the government's defeat occurred because the unusual uncertainty inherent in the circumstances caused it to miss a Condorcetwinning proposal unearthed by the political opposition. More plausibly, perhaps, both the government and the opposition were competing to shape public opinion in an unusually fluid political environment. Just as an athlete with intrinsically superior skills might have a diminished advantage if the boundaries of the playing field are invisible, so too the uncertainty of the emergency environment is a randomizer that can reduce, rather than enhance, the government's preexisting political advantages.

\section{CONCLUSION}

I do not deny either that (1) in these episodes, executives acquired broad new legal powers through legislation or that (2) causally, the circumstances of emergency legislation invoked by civil libertarian critics played a role in producing those new powers. I take both of those things to be true, in the first case because it is patently true in fact and in the second case for the sake of discussion.

Rather, I advance several more limited claims: (1) Rational legislators will delegate new powers to the executive in response to new

106 See YouGov Poll Biased Questions on 90 Days Detention without Charge, Spy Blog (Nov 7, 2005), online at http://p10.hostingprod.com/@spyblog.org.uk/blog/2005/11/yougov_poll_biased _questions_o.html (visited June 8, 2008) (attacking the poll questions as biased and vague).

107 See Point-by-Point: Terror Debate, BBC News (Nov 9, 2005), online at http://news.bbc.co.uk/ 2/hi/uk_news/politics/4421518.stm (visited June 8, 2008). 
threats. $^{108}$ (2) The very circumstances that cause boundedly rational or nonrational legislators to delegate new powers to the executive have dual effects; they also bolster the civil libertarian opposition and hamper the executive's ability to obtain new powers. (3) One cannot say anything general about how these dual effects will net out, although one can assess their net effect in particular cases. (4) One cannot impeach emergency lawmaking on process grounds without considering both sides of the ledger in detail in particular episodes. (5) Measured from the baseline of the executive's initial proposals, rather than from the baseline of the legal status quo ante, executives in all three episodes lost a great deal; legislatures substantially reined in the executive proposals. (6) The same is true even relative to the baseline of what executives really wanted, as opposed to what they asked for. Although it is, of course, harder to discern true preferences, I believe that there is substantial indirect evidence that the executive proposals in these cases at least in part embodied genuine policy preferences, rather than strictly strategic negotiating positions. Executives incurred large political costs in an effort to obtain their proposals, made noncredible threats that incautiously revealed their true preferences, and continued to defend their proposals even when the relevant legislatures had rejected them. (7) In sum, executives partially lost control of the process in all three cases, and emergency circumstances constrained delegation as well as encouraged it.

Taken together, these claims, if correct, undermine the civil libertarian argument that impeaches the processes of emergency legislation and thereby indirectly impeaches the resulting statutes. One may still, of course, advance the substantive claim that the legislatures in these episodes conferred too much power on executives, compared to some ideal benchmark (derived from moral or democratic theory or from constitutional law). I also believe that the substantive scope of the statutory delegations in these cases did not go beyond what a rational legislature motivated to maximize social welfare would grant. ${ }^{100}$ The validity of that thesis, however, is not relevant here. What I do suggest is that the circumstances of emergency lawmaking do not systematically push delegations beyond the ideal point, however defined; rather, their effects are unpredictable and may even result in insufficient delegation in particular cases.

108 See Aghion, Alesina, and Trebbi, 119 Q J Econ at 594 (cited in note 2).

109 See Posner and Vermeule, Terror in the Balance at 5 (cited in note 9) (arguing on welfarist grounds for broad deference to the executive by the legislative and judicial branches during emergencies). 